\title{
INTERRELATEDNESS OF LEGAL VERSES IN SURAH AL-BAQARAH
}

\author{
Jamilah \\ Fakultas Syariah UIN Maliki Malang \\ Telepon: 081586183074 \\ Email:Zhenit79@Yahoo.com
}

\begin{abstract}
This paper will examine the interrelatedness of the Quranic verses, and how every verse is put in a well logical arrangement. The approach used in this examination is what the Quranic science calls 'Ilm al-Munâsabah. This specific Quranic science aims to find the relation between one verse with the other which precedes and follows it. Different issues, styles, time and occasions of revelation in one chapter are not a hindrance to find the correlation between the verses of the same chapter. Due to its various legal contents, surah al-Baqarah will be the focus of the discussion.

Artikel ini meneliti keterkaitan antar ayat al-Quran dan bagaimana setiap ayat diposisikan dalam urutan yang logis. Pendekatan yang digunakan dalam tulisan ini adalah apa yang dikenal sebagai ilm munasabah al-ayat. Ilmu al-Quran ini berupaya menemukan keterkaitan antara satu ayat dengan ayat sebelum dan sesudahnya. Ragam tema, gaya, waktu dan asbab al-nuzul dalam sebuah surat tidak menjadi hambatan untuk menemukan hubungan antarayat dalam surat yang sama. Karena kandungan ayat hukumnya yang beragam, surat al-Baqarah menjadi fokus kajian dalam artikel ini.
\end{abstract}

\section{Keywords:}

\section{Introduction}

The method used by the Quran to promulgate its rulings differs from that of canon law or books of jurisprudence (fiqh) which usually puts its specific rulings in one specific chapter, or put different rulings in more than one chapter. Quranic rulings on the issue of praying or alms giving, for instance, are not found in one single chapter, which is commonly used in the book of jurisprudence. Instead, the Quran spreads its rulings in various chapters with many diverse styles; sometimes they come in the form of advice, story, or prohibition. In addition, the Quran also mentions diverse issues in one chapter. By mixing different issues in one place, the Quran gives the readers an understanding that one issue is as important as the others. The different structures and styles will avoid the
This unique style of arrangement constitutes the inimitability ('ijâz) of the Quran. It is interesting to find that even though the Quran were revealed in more than two decades, we find its verses interrelated with one another; it makes an organic unity which is unlikely to be separated. This close relationship between one verse with that precedes and follows it has been claimed as the proof of the inimitability of the Quran. It is claimed that despite the different period and occasion of revelation, the verses of Quranic chapters show striking relation with one another, as if it was revealed in one night. Were it created by humankind, the Quran does not have the structure and arrangement as it does now.

In this paper, the writer will examine the second chapter of the Quran, i.e Surah al- 
first to be revealed in Medina. It was revealed in the period of 9 years, and consists of many different issues, ${ }^{1}$ therefore it gives us a very good example of how ilm al-munâsabah is put to work in this chapter. The writer will focus more on the examination of the legal verses of the chapter and will limit the discussion from verse 163 to the end of the chapter.

\section{Legal Verses in Surah al-Baqarah}

To begin with, this chapter is opened by the verses mentioning three types of people in responding the Quran and their respective reward and punishment (Q.S. 2:2-20). Unlike the first and second group, i.e. believer (mu'min) and unbeliever (kafir), the third group, hypocrite (munafiq), is described in length (Q.S. 2:8-20). Then it proceeds to call all humankind to worship God by providing the proof of creation in Earth and reminding them of His blessing, the most important of which is the revelation (Q.S 2:21-29). Then the story of Adam's creation and vicegerent follows (Q.S. 2:30-39). After that, the chapter mentions the story of Israelite in length (Q.S. 2:40-141).

The rest of the chapter mostly deals with the legal, ethical and ritual issues, including the rulings on personal and communal behavior and activities, within both conjugal and social life. Therefore in this chapter we find legal issues on retaliation, testament, fasting, wealth, food and beverage, orphanage, marriage, interest, and debt, to mention only a few. In the middle of these issues, the story of Israelite and Abraham was again mentioned. The chapter is closed by verses mentioning the basic faith which is parallel to the issues of its first verses.

Verse 163 explains the oneness of God and that $\mathrm{He}$ is the only deity entitled to be worshiped. One of the Quranic methods in proving the oneness of God is by combining the doctrine of belief with the natural phenomena and historical events (Q.S. 2:164). These God's signs in the universe aim

\footnotetext{
${ }^{1}$ Abu Bakr Muhammad ibn Arabi, Ahkâm alQur'ân (Cairo: Dâr al-Manâr, 2002), vol. 1, p. 24.
}

to encourage humankind to think and contemplate. In the previous verses, we find the story of Ka'bah and maqam Ibrahim (Q.S. 2:125-129), the changing of praying direction (qiblah) toward Ka'bah (Q.S. 2:142-145), and $s a^{\prime} y$ between mount Safa and Marwah (Q.S. 2:158). By mentioning these places and events, God reminds the believers that all of them are not meant to be worshiped. ${ }^{2}$ It has been the custom for the people during the time of the Prophet to come to Mekka to worship their idols placed around Ka'bah, in such a manner that they have a strong emotional relation with Ka'bah. ${ }^{3}$ The Quran aims to eliminate this attitude of worshipping idols and $\mathrm{Ka}$ 'bah, to gether with all of the rites related to the ceremonial activities around Ka'bah. The abovementioned verse comes to purify this pilgrimage from the polytheistic nature which associates God with His creations. It is clear then how this verse related closely to the previous ones. This verse also give us a clue that God is the source of all creations and legislation. However, there are people who do not use their intellect to contemplate God's signs and make partners with God.

The relation between verse 165 and the previous ones is indicated by the conjunction (hurf 'ataf) in its beginning. While the previous verse mentions the people who use their intellect and believe in the oneness of God after contemplating God's sign in the universe, this verse mentions the people who do not find guidance from those signs and, due to their ignorance, take partnership with God. Then the following verse (Q.S. 2:168) directs its call to all humankind to eat good food. This verse comes only after the oneness of God and His blessing for humankind has been established in the previous verse, and shows us that God's blessing is so overwhelming that $\mathrm{He}$ indiscriminately

2 Abu Bakr Muhammad ibn Jarir al-Tabari, Jâmi 'al-Bayân 'an Ta'wîl Ây al-Qur'ân (Beirut: Dâr al-Fikr, 1984), vol. 2, p. 60.

3 Abu Abd Allah Muhammad al-Qurtubi, alJâmi ' li Ahkâm al-Qur'ân (Beirut: Dâr Ihyâ' al-Turâth al-'Arabî, 1985), vol. 2, p. 203-4. 
provides people with good sustenance. ${ }^{4}$ This verse becomes the basis for promulgating the ruling concerning food and beverage.

The following verse (Q.S. 2:172) mentions the ruling on good food for believers, because they are considered as people who are worthier and better-suited to take heed to God's command and prohibition. The believers are expected to understand that it is God alone who has the right to legislate. Belief in God as the only creator naturally leads to the belief in the God as the sole legislator. ${ }^{5}$ The verse specifically addresses the believers because they are the only group of people who will listen and obey God's command regarding the food and beverage.

Then in verse 174 God warns the believers not to follow the path of the People of the Book who conceal the words of God and sell them at a low price. In this verse God is not pleased with the attitude of concealing His words and using them for their worldly benefit. The verse mentions that what they did is tantamount to buying the darkness with the lightness and eating the hellfire.

After preparing the soul for further commands and prohibitions, the following verse (Q.S. 2:177) describes the picture of true belief and the way to obtain it. This verse relates strongly to the previous one about the changing of praying direction. This verse explains that directing one's face toward the West or East in praying is not at all a sign of faith or virtue, since the real faith and virtue is having a strong belief in God and doing good deeds as enumerated in the verse concerned. This verse compiles perfection of humanity, which is the true belief, good social relationship, and refined soul. This verse is closed by God's praise on patience in distress, affliction and tribulation, which is considered as the highest type of patience and the true sign of belief.

Verses 178-180 deals with the issue of retaliation (qisas) and testament (wasiyah), which is encouraged upon a person when he

4 Fakr al-Din Muhammad ibn Umar al-Razi, Tafsîr al-Kabîr (Beirut: Dâr Ihya' al-Turâth al-'Arabî, n.d.), vol. 5, p. 2. See also Qurtubi, vol. 2, p. 208.

${ }^{5}$ Ibid., p. 9. or she sees that the death signs are approaching, such as being on death row or severe illness. ${ }^{6}$ There is an obvious relation between verse on qisas and that on wasiyah. When God stipulates that the heirs of the killed person have the right to take retaliation, the person committing murder is entitled to have a death sentence. In this particular state of inevitable death, a person is encouraged to make a testament for his/her parents or relatives.

After promulgating the law concerning retaliation which deals with human body and testament which involves the distributing of wealth, the following verse (Q.S. 2:183) deals with fasting which is the fourth pillar of Is lam. In the middle of rulings on fasting, we find the verse on prayer (Q.S. 2:186). This means that there is close relationship between fasting and prayer, in which by doing sincere fasting, believers are getting closer to God since during fasting month, believers are trained to obey God's command in abstaining themselves from eating and drinking which are permissible during other eleven months. The true believers will use their night of fasting month to pray and recite Quran as a means to get closer to God who is all Knowing and Hearing of their good deeds and prayers. And God will answer their prayers, give them their rewards, strengthen their heart and encourage them to do more good deeds and prayers.

After mentioning the rulings on fasting which obliges believers to abstain from eating and drinking during the day, the following verse (Q.S. 2:188) mentions the prohibition of illegally "eating" the wealth of others, since this act will eliminate all the good deed the believers might have done during the fasting month. Therefore, the relation between this verse and the previous one is establish by the fact that both verses dealt with the prohibition to trespass the limit (hudud Allah).

Following the rulings on fasting, verse 189 mentions the moon which is one of God's sign in nature. The relation of this

\footnotetext{
${ }^{6}$ Ibid., p. 57.

${ }^{7}$ Ibid., p. 94.
} 
verse with the previous one is obvious, because decision to start the fasting month is by seeing the moon. This verse also mentions about pilgrimage, which is the fifth pillar of Islam. While the first part of the verse mentions the moon and the pilgrimage, the second part mentions the custom of preIslamic Arabs during the pilgrimage season, in which they will come into their house from the back door. ${ }^{8}$ This verse is revealed to stop this custom by explaining that the virtue does not lie in the physical movement, but in the deep of the heart.

The verses on pilgrimage (Q.S. 2:189200) are then interrupted by the permission to wage war against unbelievers during the pilgrim months (asyhur al-haram) or even within the Masjid al-Haram (Q.S. 2:190-191). These verses on war seems to be out of context, but the occasion of revelation clearly shed the doubt about the relationship between these two verses with the general issue of pilgrimage. ${ }^{9}$ It was related that these verses were revealed a year after the Hudaybiyah agreement. In that year, the Prophet and his companions wanted to go for umrah, but he was worried that the Quraish will force them out of Masjid al-Haram or wage war against them during the months of pilgrimage, whereas the fight during these sacred months was detestable in that time. Therefore the Prophet was in a dilemma. It was in that situation that this verse was revealed to inform the Prophet that he can fight for defense during that month. ${ }^{10}$ It was clear then that the permission to wage war is closely related with the main issue of pilgrimage.

When Mekka was liberated from the grip of the Quraish, pilgrimage can be performed freely. Therefore verse 196 commands to complete the rites of pilgrimage that was not done in a complete manner before the taking over of Mekka (fath alMakkah). These series of verses on the rulings of pilgrimage (Q.S. 2:189-200) are

\footnotetext{
${ }^{8}$ Ibid., p. 125. See also Qurtubi, p. 345.

${ }^{9}$ See Ahmad ibn Ali Ibn Hajar al-Asqalani, alUjab fi Bayân al-Asbâb (Damman: Dâr ibn Jawzî, 1997), vol. 1, p. 455.

${ }^{10}$ Ibn Arabi, p. 130. See also Qurtubi, p. 347.
}

interrupted by the verse mentioning about the trading activities during the pilgrimage season (Q.S. 2:198). This reference to trading activities is not something peculiar, because before the coming of Islam it has become a custom for pilgrims to involve in the trade during the pilgrimage season. During the pilgrimage, dispute is prohibited. It is in this context that the trade during the pilgrimage is mentioned in this verse, since it may lead to dispute. $^{11}$

Verses 204-210 give believers lesson to follow in their life. Here God give them example about two types of people. Verse 204 describes a type of person whose pray is only a lip service and whatever come from their mouth is different from what is inside their heart, and verse 207 about people who devote their life to obey God's rule. These series of verses related closely to the previous ones (Q.S. 2:200-203) in which God describes the people's motives in doing the prayers. Some of them ask for the goodness in this world and in hereafter, while other ask only the goodness in their worldly life.

In verses 211-213 the story of Israelite and unbelievers is again mentioned as a lesson for believers not to follow their stubbornness which keep them away from guidance. Through this story, the believers are encouraged to purify their heart from blemish passion and avoid themselves from slipping into ingratitude after being guided into the right path. The story of past generation comes to encourage the believers to be steadfast in their belief, because the believers before them also experienced hardship in defending their belief until God's help come to rescue them and gave them a victory over unbelievers. ${ }^{12}$ This verse tells us that paradise, which is the highest reward from God, can only be obtained by those who are steadfast in their belief and patient in facing the trials and tribulations.

11 Shihab al-Din Muhammad al-Alusi alBaghdadi, Rûh al-Ma 'ânî (Beirut: Dâr Ihyâ' al-Turâth al-'Arabî, 1975), vol. 1, p. 87.

12 Ibid., p. 103. See also Muhammad Tantawi, al-Tafsîr al-Wasîth li al-Qur'ân al-Karîm (Cairo: Matba'ah al-Sa'âdah, 1977), vol. 1, p. 629. 
While the previous verses mention about Paradise and that the way to achieve it is full of difficulty and burdensome, verse 215 tells us about the charity, which is also a means to obtain Paradise. ${ }^{13}$ The following two verses tell us about waging war against the enemy who oppresses the believers. Both charity and jihad mean sacrificing something precious. In charity, we spend our wealth and in jihad we sacrifice our life. ${ }^{14}$ Those who obey God's command to do the charity and join jihad will enter Paradise. Here we see the relationship between the se three verses.

How to spend wealth in God's course becomes the main point of the following verse (Q.S. 2:219). This verse tells us that spending money on Khamr and gambling is a sinful act. The harmful effect of wine and gambling is obvious. Both might have benefit, but the benefit is outweighed by the clear harm that they cause on mind and religion. This verse is the beginning of the process of prohibiting wine, and the clear prohibition on wine will be revealed in Surah al-Maidah. Instead of spending the wealth on wine and gambling, this verse advises believers to spend it on charity. However, what we spend for a charity is whatever we can spare above the needs of our family. In other words, charity is given after the family basic need has been fulfilled. A group of people who are most eligible to receive the charity, which are the orphans, is mentioned in the next verse (Q.S. 2:220). The main point of verse 220 is how to manage the orphan's property, which is under our control. We are told that there is no harm in mixing our food and drink with theirs, since they are our brothers in the religion, because God knows those whose intent is to cause mischief or righteousness.

Then, the context of Quranic discourse moves to the issues on marriage, divorce, waiting period (iddah), breast feeding (rada'ah), engagement (khitbah), temporary marriage (mut'ah) and other marital issues (Q.S. 221-242). The first issue mentioned in these series of verses is inter-religious

\footnotetext{
${ }^{13}$ Ibid., p. 106.

${ }^{14}$ Ibid., p. 107.
}

marriage (Q.S. 2:221). The prohibition to marry idol-worshipping women (musyrikah) is obvious, because the foundation of family life will be collapse unless both husband and wife are in good term in religious convictions. The relationship between this verse and the previous one is established by the fact that the marriage with the orphans under our care is possible and permissible, as long as it is done by sincere intention, not under the motif of confiscating their wealth, and this verse mentions the marriage which is prohibited, that is the marriage with idolworshippers. Even though the meaning of this verse is general and includes every musyrikah from among the idol worshippers and the People of the Book, the later is excluded from this ruling by Q.S. 5 :5. ${ }^{15}$

Then verse 222 tells us about the proper manner in conjugal relationship. We are told that sexual intercourse during women menstruation is prohibited as well as anal sex. ${ }^{16}$ While the previous verse prohibits marriage with certain women, this verse prohibits sexual intercourse with wife in certain condition. Then while keeping in mind that sexual intercourse during menstruation and anal sex is prohibited, verse 223 tells us that a husband may go in to his wife when he likes and as he likes.

Verse 224 is preliminary to the issue of oath to one's wife (ila') and divorce in the following verses. It was a custom of the Arabs to swear in God's name to refrain from pious acts and severe relations with the relatives. Then this verse comes to prohibit swearing to abandon a good deed, and continuity in a sinful vow is more sinful than breaking it by expiation. However, when the vow is broken, the kafarah should be paid, and it is better to break the vow than to continue in a sinful vow. ${ }^{17}$ Then the next verse tells us that unintentional vow is not

${ }^{15}$ Al-Alusi, p. 118. See also Hikmat ibn Bashir ibn Yasin, al-Tafsîr al-Sahîh (Medina: Dâr alMa'âthir, 1999), vol. 1, p. 332.

${ }^{16}$ Ibid., p. 124. See also Muhammad ibn Yusuf al-Andalusi, Tafsîr Bahr al-Muhîth (Beirut: Dâr alFikr, 1983), vol. 2, p. 169.

${ }^{17}$ Al-Asqalani, p. 576-7. 
accounted for, because it is just like the habitual statements that the tongue repeats, without really intending them. This verse refers to the habit of the Arabs to vow by their idols, and this habit still very much observed by the time of the Prophet. By habit, some new Muslims vow by their previous idols. Therefore the Prophet ordered them to intentionally recite shahadah in order to eradicate their vow. ${ }^{18}$

Verse 226 relates to the is sue of Ila', a specific kind of vow in which a man swears that he will not sleep with his wife for a certain period. Ila' in pre-Islamic Arab has no limit, that compels a woman to pass her life in bondage. ${ }^{19}$ This verse abolishes that injustice practice and limits ila' only for 4 months, after which the husband is required to return to his wife or divorce her. This verse ends with divorce, so it is a natural order that the next verse is talking about this issue.

The reader of the previous verse has been told about the two possible consequences of ila', in which one of them is divorce (talaq). So it is not surprising that the next verse (Q.S. 2:228) talks about the ruling on a divorced woman, in fact, the reader is prepared to follow this issue. The previous two verses and this verse also talk about the waiting period (iddah), even though the cause and the length are different. From the historical perspective, these three verses were revealed to abolish some pre-Islamic Arab's practices. Both ila' and divorce practiced by the Arabs are often put woman in bondage, having neither the position of wife nor that of a divorced woman free to marry with another man. These verses on ila' and talaq also limit the waiting period of ila and talaq, and stipulate that the divorce is thrice, meaning that the divorce becomes irrevocable after the third. In the period of ignorance (jahiliyah) the husband had the right to take back his divorced wife even if he had divorced her a thousand times. ${ }^{20}$ This situation was harmful

18 Ismail ibn Umar ibn Kathir al-Dimasqi, Tafsîr al-Qur'ân al-'Azhîm (Beirut: Dâr Ibn Hazm, 1998), vol. 2. p. 556.

\footnotetext{
${ }^{19}$ Ibn Yusuf al-Andalusi, p. 180.

${ }^{20}$ Ibid., p. 191. See also al-Asqalani, p. 572.
}

for the wife. By limiting talaq into three times, it is safe to say that these verses bring about a reform in the relations of husband and wife.

Some issue relating to divorce is also mentioned in verse 229. It is told that the husband is not allowed to pressure his wife to give him back the dowry (mahr) and any gift that he has given her in return for divorce. However, if the wife willingly gives it back with a good heart, then it is permissible for the husband to take it. Other form of reform relating to marital life is also introduced in this verse, in which the wife is allowed to claim a divorce by giving back her husband what he had given her, when the spouses have irreconcilable difference. There is no sin on her in this case, nor on him if he accepts such offer. Technically, such a divorce initiated by wife is called $\mathrm{khul}$.

The following verse is a continuation of the previous issues on ila' and talaq. It indicates that if a man divorces his wife for the third time, he will no longer be allowed to marry her, until she legally marries another man. However, before the third talaq, the husband has the right to return to his wife even though the 'iddah has elapsed, and the guardian (wali) of the divorced woman should not prevent her from going back to her husband. Then the verse continues with the issue of breast-feeding (rada 'ah). It is natural that marriage might consequently be followed by motherhood. In verse 233 , mothers are encouraged to suckle their infants through the complete term of suckling, which is two years. The issue of rada'ah has a close relationship with that of divorced women, because it often happens that a divorced woman has an infant with her and she is suckling it. In this case, the father of the infant is required to provide proper expenses and clothes. ${ }^{21}$

The bond of marriage is broken not only by divorce but also by the death of one spouse. In verse 234 we are told that iddah for the widow is different from that of the divorced. However, if the widow is pregnant,

\footnotetext{
${ }^{21}$ Tantawi, p. 696-7.
} 
her iddah finishes when she gives birth. 'Iddah for a widow is meant to be a time of mourning, and also, like any other types of 'iddah, as a waiting period to see whether or not the womb contains a fetus. By mentioning 'iddah of widow, this verse implicitly prohibits a marriage proposal (khitbah) to the widow during the mourning period. However, the next verse (235) allows Muslim men to make an indirect and general marriage proposal to the widow during her iddah. The man can say to her, for instance, that he wishes to marry, or desires a wife, or looks for a good wife. ${ }^{22}$

While the previous verses talk about different type of divorces that entitle iddah, verse 237 speaks about a divorce that requires no 'iddah. If a woman is divorced before consummating the marriage, she has no 'iddah. We are told that a husband is to give his divorced wife a gift of a reasonable amount to compensate for her loss. However, if the dowry has been mentioned, he should give her half of the dowry if she is divorced before the marriage is consummated.

The issue of marriage and divorce is then interrupted by that of praying (Q.S. 2:238-9). There seems no close relation between marriage and praying. However, the relation could be in the idea that the marital and family problems, especially divorce, which might make the concerned parties frustrating, should not make them forget about their obligation to perform the praying on the prescribed time. In the middle of resolving this pressing family problem, they are urged to get closer to God and fear Him. This verse suggests them to take a pause and ask God for help through praying. ${ }^{23}$ We can also suggest that, just like praying, an effort to solve the family problem is also a kind of obedience to God.

The emphasis on praying in the first verse is also due to the fact that praying might be neglected during wars. Praying is so important that it should be done even when we are in battlefield. And the battlefield for the husband and wife is their household. We

\footnotetext{
${ }^{22}$ Ibn Kathir, p. 588.

${ }^{23}$ Ibid., p. 719-20.
}

can also build the relationship between wars, dealt in this verse, and widowhood, dealt in the previous ones. The question of widowhood is closely associated with fighting, since wars must increase the number of widows. ${ }^{24}$

Verses 243-244 talk about jihad and its reward. God's command comes in various forms, from praying to fighting in His course, the purpose of which is to test the people which of them are true believers. Both praying and fighting require the same degree of obedience. Someone who performs praying, but refuses to join fighting in His course, is not counted as a true believer, since a true believer is never selective in obeying God's command. Obeying some commands while neglecting others is one sign of hypocrisy every believer should avoid of.

Jumping from one issue to a totally different one is among the custom of the Quran in delivering its teachings. It is also among the method of the Quran that after promulgating the legal injunction, it mentions the story of past generation as a reminder for the believers to obey God's command. The readers are encouraged to learn from what has befallen upon their predecessors. The story of the past nations also functions as a warning for the people not to oppose God's command. In verses 246-252 we are told about the story of Israelite and warned believers not to follow their footsteps. Many prophets have been sent to urge them to be grateful to God. Among the greatest prophets sent to Israelite are David and Moses.

The following verse tells us that each prophet has his own excellence; therefore it is prohibited to prefer some prophets above the others. It's not us who decide which prophet is better, for it is Allah's decision. It is God Himself who has the privilege to place some prophets in a higher degree above the others. Our duty is to submit, obey, and believe in God's decision. Then verses 254-255 describe some of our duties to God and society.

${ }^{24}$ Maulana Muhammad Ali, The Holy Quran (Ohio: Ahmadiyyah Anjuman Isha'at Islam, 1963), p. 104. 
Spending our wealth in God's cause become the main point of verse 254, and will be dealt in length in the following verses. Spending wealth and raising funds are very critical for carrying on the struggle for existence against numerous enemies who are relentlessly fighting the believers.

Due to its importance, the issue of spending wealth in God's cause is dealt in 14 verses (Q.S. 2:261-174). Striking relationship between verse 261 with previous ones (Q.S. 258-260) is established by the fact that while Abraham asks God about resurrection of the death in verse 261 , God gives parable about one seed that grows into seven ears and in every ear a hundred grains. The parable aims to show that whoever is capable of doing that is also capable to resurrect the death. ${ }^{25}$ This verse also tells us about the reward of spending wealth in God's cause, in which God will multiply it by seven hundred times. However, the parable in this verse is more impressive on the heart than merely mentioning the number of seven hundred. This verse indicates that God "grows" the good deeds for its doers, just as He grows plants for whoever sows it in fertile land. This immense reward is only obtained by those who are sincere in their deeds. Therefore, the following verses (Q.S. 2:262266) tell us about the prohibition of reminding the charity, whether this takes the form of words or actions, because such attitude will only annul the reward of charity. Again, here we are provided with the parable of people doing charity to show off to people. This person pretends to give away charity for God's sake, but in reality seeks to gain people's praise and the reputation of being kind or generous, or other material gains of this life. ${ }^{26}$ This insincere charity is described as "smooth rocks in which a little dust is wipe out by the heavy rain, and left completely barren." 27

The parable of the sincerity in giving away charity is repeated in verse 265 . The repetition is also among the method of the

\footnotetext{
${ }^{25}$ Ibn Yusuf al-Andalusi, p. 303.

${ }^{26}$ Ibid., 309.

${ }^{27}$ Q.S. 2:264.
}

Quran to deliver its message and to emphasize the importance of the concerned act or command. This verse gives us parable about those who give away charity for the sake of God. Their sincerity is like a fertile garden upon which seed will eventually grow into fruitful trees. If heavy rain does not fall on it, slight rain or dew will suffice for it. On the contrary, those who follow their good deeds with evil deeds will find their previous good deeds annulled, just like a beautiful garden with date palms and vines which is stricken by the lighting storm.

In the following verses (Q.S. 2:267268 ), we are told to give away a charity from pure wealth. The following verse enjoins us to support God's cause by spending good things that we love, not bad things which we ourselves would not accept from others. God likes and only accepts purity and goodness, and God is Rich and free from any needs. The reason for this command to give away charity, among others, is to help the poor people and to make fewer gaps between the rich and the poor. By promulgating His command to give away charity, He does not intend to make people impoverished. Someone who holds his wealth and refrains form spending it in God's cause has indeed false fear of becoming poor. This fright of poverty is actually encouraged by the Devil who whispers into the heart on humankind and incites him to disobey God's command and do evil things. ${ }^{28}$

The charity can be spent both in secret and openly. Even though verse 264 prohibits us from showing off the charity, verse 271 and 274 tell us that disclosing charity publicly has an apparent wisdom, such as to encourage people to imitate this righteous act. Especially when the country needs the charity for national defense or public utility, manifesting charity or giving alms openly will encourage people to lend support for the national welfare.

In verse 272 God's guidance (hidayah) is related with charity. It is understood from this verse that the charity from the believers

\footnotetext{
${ }^{28}$ Tantawi, p. 810-811.
} 
not only for the welfare of their own coreligionists, but also for that of non-believers, since God does not allow the difference of religion becomes a hindrance to the bestowal of charity upon a deserving person. ${ }^{29}$ It is also clear from this verse that all the support from Muslim community for the national welfare should be based on the sympathy towards humanity, and not to bring people into the fold of Islam, because the duty of guiding people is only in God's hand. ${ }^{30}$

While God promises the believers great rewards and prosperity for the charity they give in God's cause, in verse 275 God prohibits them to amass wealth by practicing usury (riba). Unlike charity, usury is oppressive in nature; charity is based on human sympathy, but usury annihilates all sympathetic affection and leads to extreme misery. Usury also stands of quite different footing from trading. In trade, people take the risk of loss, but in usury, a man who borrow the money on usury suffers the whole loss. In other words, even in the case of loss, the lender will always take his profit from the usury. Therefore, unlike trade, usury leads to the accumulation of wealth in the hands of the rich and the deterioration of the poor. In addition to the harm upon the society, usury also gives a bad effect on morality, as it cause men to be obsessed by love of wealth and selfishness. ${ }^{31}$ At the end of verse 276 , we are told that those who practice usury are considered unsatisfied with the permissible and pure resources. Instead they try to illegally amass wealth by relying on evil method. "God dislikes these ungrateful sinners." 32 After prohibiting usury, the following verse (Q.S. 2:277) talks about the institution of zakah (alms), according to which one-fortieth of the amassed wealth of the member of society is taken in a yearly basis to be distributed among the poor.

The prohibition on usury is explicitly stated in verses 278-9, in which the practice of usury is tantamount to waging war against

\footnotetext{
${ }^{29}$ Muhammad Ali, p. 119.

${ }^{30}$ Ibid.

${ }^{31}$ Ibid., p. 120-21.

${ }^{32}$ Q.S. 2:276.
}

God and His prophet. Therefore, believers should abandon whatever left of usury, and take only the original capital, without increase or decrease. And in case where the debtor has a hard financial problem, the creditor is encouraged to give him respite. In the end of verse 281 , all parties involving in lending and borrowing money are reminded of the day of judgment where they will return to God and "every soul will be paid in full what it has earned, and they will not be wronged." $" 33$

The issue of trade and usury dealt in the previous verses brings us to the subject of writing down the loan contract. In this verse, God directs believers to record their loan transactions when the term is delayed. The fact that most of the Arabs at that time are illiterate, and God still commands them to write down all their transactions, big or small, indicates the necessity of having records for transactions. And in order to avoid dispute, God commands believers to bring witnesses to attend the writing of contracts. As women did not take much part in business at that time, and were therefore unable to understand the transaction, two women are equal to one man. In regard with the writing of a loan transaction, an exception is made in verse 283 , in which security deposit (rahn) could be submitted if one cannot find a scribe to record the debt. However, if both parties trust each other, there is no harm if they do not write the transaction or have witness present. In this case, both parties are obliged to keep the trust (amanah) and should not hide testimony (shahadah). In the following verse, we are told that God knows whether we manifest what is in our heart or conceal it. This chapter is closed with verses concerning the basic faith, which has been dealt in the first verse of this chapter.

\section{Conclusion}

From the discussion above, we can see a unique structure and arrangement of the Quranic verses. In its organic unity, Surah alBaqarah resembles a garden with colorful

${ }^{33}$ Q.S. 2:281. 
flower whose beauty and well arrangement amazes whoever comes to see it. The eloquence of the Quran in delivering its message cannot be imitated by any mortals; none of the well verse Arab poets and prose writers can produce its like, even by helping each other in so doing. Some of them may excel in heroic poetry, for example, but not in

\section{BIBLIOGRAPHY}

Ali, Maulana Muhammad, The Holy Quran (Ohio: Ahmadiyyah Anjuman Isha'at Islam, 1963).

al-Alusi, Shihab al-Din Muhammad, Rûh alMa 'ânî (Beirut: Dâr Ihyâ' al- Turâth al'Arabî, 1975).

al-Andalusi, Muhammad ibn Yusuf, Tafsîr Bahr al-Muhîth (Beirut: Dâr al-Fikr, 1983).

Ibn Arabi Abu Bakr Muhammad, Ahkâm alQur'ân (Cairo: Dâr al-Manâr, 2002).

al-Asqlani, Ahmad ibn Ali Ibn Hajar, al-Ujab fî Bayân al-Asbâb (Damman: Dâr ibn Jawzî, 1997). love poetry. The Quran, by contrast, consists on numerous subjects and uses many forms of style which have equal degree of eloquence. This versatility is impossible for human to imitate and this proves to us the inimitability of the Quran whose style is beyond teaching or learning.

Ibn Kathir, Ismail ibn Umar, Tafsîr al-Qur'ân al-'Azhîm (Beirut: Dâr Ibn Hazm, 1998).

al-Qurtubi, Abu Abd Allah Muhammad, AlJâmi' li Ahkâm al-Qur'ân (Beirut: Dâr Ihyâ' al-Turâth al- 'Arabî, 1985).

al-Razi, Fakr al-Din Muhammad ibn Umar, Tafsîr al-Kabîr (Beirut: Dâr Ihyâ' alTurâth al-'Arabî, n.d.)

al-Tabari, Abu Bakr Muhammad ibn Jarir, Jâmi' al-Bayân 'an Ta'wîl Ây alQur'ân (Beirut: Dâr al-Fikr, 1984).

Tantawi, Muhammad, Al-Tafsîr al-Wasîth li al-Qur'ân al-Karîm (Cairo: Matba'ah al-Sa'âdah, 1977).

Ibn Yasin, Hikmat ibn Bashir, Al-Tafsîr alShahîh (Medina: Dâr al-Ma'âthir, 1999). 